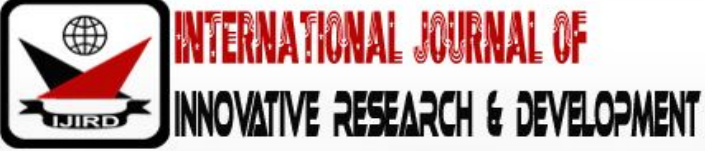

ISSN 2278 - 0211 (Online)

\section{Taming Corruption in Africa: A Comparative Examination of South Africa and Nigeria}

\author{
Olawale Akinrinde \\ Lecture, Department of Political Science, Osun State University, Nigeria \\ Bolaji Omitola \\ Professor, Department of Political Science, State University, Nigeria
}

\begin{abstract}
:
South Africa and Nigeria are no doubt two giants in terms of economy and leadership potentials in Africa. These countries however have a Common Enemy in corruption which has the potential of undermining both their political and economic advancements. In Africa, corruption has become an endemic issue which is seriously affecting development of the continent and therefore continues to attract scholarly and popular discourse. This paper interrogates the issues of corruption in the two countries by drawing references from some celebrated cases such as the subsidy affairs and the bullet proof car scandal cases in Nigeria; and corruption charges against President Zuma and the Nkandla affairs in South Africa. These cases are examined within the context of anti-corruption institutional framework in the public service, anti-corruption law enforcement infrastructure and monitoring and oversight of incidence of corruption in the two countries. The paper observes that while there are varying levels of successes of anti-corruption crusades in the two countries, there are still challenges of excessive political interference, problem of socio-cultural perception of corruption, delay process of resolving corruption cases encouraging impunity and creation of culture of "untouchables". In terms of transparency in the discourse and handling of corruption issues, Nigeria still has a lot to learn from South Africa. This paper concludes that a lot still needs to be done not only at the level of policy making or establishment of anti-corruption infrastructure but specifically at "Walking the talk" in terms of actual commitment to mitigating corruption in the two countries.
\end{abstract}

Keywords: Africa, corruption, anti-corruption crusades, Nigeria and south-Africa

\section{Introduction}

Although corruption has long been identified as, because of its devastating effects, the greatest threat to the development and continued existence of every state, most especially, the third world states. It is however, not until recently, that it is attracting the required attention in the discourse of Third world states' underdevelopment. The subject of corruption is not only attracting more attention presently than it once did but its indispensability in understanding Third world states' underdevelopment is now widely acknowledged and appreciated. In fact, it has been argued that, based on the plethora instances of high-profile corruption cases in South Africa that is purportedly seen as a relatively developed country and Nigeria within the Third world region, corruption now manifests as a global pathological problem which is not only confined to the shores of Africa and other Third world countries but whose causes, manifestations and consequences vary from one society to another (Gupta, 1995). However, unlike the developed region, corruption alone accounts for the greatest predicament of poverty and underdevelopment bedeviling the African continent (Okojie and Momoh, 2005). While South Africa fares better in development terms than its Nigerian counterparts, both countries are still deep-rooted and neck-deep in the menace of corruption. Although, corruption accounts for the economic woes in both countries at varying degrees, its continued persistence may hinder the full realization of each of the country's potentials, and as a consequence, have serious consequences on Africa's development in general owing to the importance and leadership positions occupied by these two countries in Africa.

In recognizing the need to curb and fully ground the menace of corruption before it grounds the development agenda of both countries, South Africa and Nigeria have, in the past, taken some measures through political and economic reforms as well as setting up anti-corruption agencies with a view to minimizing and eradicating corruption. Nigeria established the Code of Conduct Bureau, the Independent Corrupt Practices and Other Related Offences Commission (ICPC), and the Economic and Financial Crimes Commission; South Africa, in the same logic, is prosecuting the war against corruption through its National Prosecuting Authority (NPA). However, despite the number of cases of corruption that have been identified and prosecuted by Anti-corruption agencies in Nigeria and South Africa, it remains evident that the anti-corruption crusades in both Nigeria and South Africa have not really yielded substantial results (Enweremadu, 2012; Egwemi, 2012). Although, South Africa has fared better in taming and prosecuting corrupt cases than Nigeria, both 
countries still, nevertheless, have poor records in the prosecution of high-profile cases. The Stella Oduah car scandal and the Subsidy scandal are undoubtedly high-profile cases that continue to be sacrificed on the altar of politics in Nigeria. While legal proceeding was instituted against the former Minister of Aviation, Stella Oduah in 2013, under former President Goodluck Jonathan, for the purchase of two armored BMW cars worth 255 Million Naira without due process and strict adherence to the Procurement Act of the Federal Republic of Nigeria, the 2011 subsidy scam was without doubts one of the greatest corrupt cases that continues to linger till date in Nigeria. Similarly, Nkandla affairs involving President Zuma on the upgrading of his home which was valued at 216 million rand (then $\$ 24$ million) in 2014, has equally become a symbol of alleged corruption and greed within South African political landscape. It should be noted that while the National Prosecuting Authority dropped all legal actions against President Jacob Zuma on the Nkandla affairs in 2015 in South Africa before it was revisited again due to public pressure, the Stella Oduah's car scandal has been in court since 2013 with several litigations with no appreciable legal conclusion reached yet. Although, there are strong pressures on the National Prosecuting Authority in South Africa to revisit the Nkandla case, the case might end up being delayed in the long run due to its connection with high profile politicians in South Africa. This equally explains why high-profile corrupt cases are tactically delayed in Nigerian and other African countries due to excessive political interference. Comparatively therefore, South Africa may have fared better in its anti-corruption crusades than Nigeria, high profile corrupt cases are still very much evident in both countries. Hence, taming corruption in these two countries may never yield the desired results if the invisible hand of politics is not completely removed from the anti-corruption crusades in these two countries.

\subsection{Understanding Corruption}

Corruption, though, has, over time been seen as a global problem, it continues to lack a universally accepted definition. While the Oxford Dictionary of Current English defines corruption as an act of dishonesty especially using bribery or an immoral or wicked act, the Oxford Advanced Learner's Dictionary sees it as a dishonest or illegal behaviour especially of people in authority. This definition looks at both the moral and legal aspects. But for Joseph Nye (1967), corruption is basically a deviation from the formal duties of a public role because of private-regarding (personal, close family, private clique) pecuniary exercise of certain types of private regarding influence. This includes such behaviour as bribery (use of reward to pervert the judgment of a person in position of trust); nepotism (appointment by reason of ascriptive relationship or sentimental affiliation rather than merit); and misappropriation (illegal appropriation of public resources for private regarding uses).

The definition by Nye (Ibid) sees corruption as a deviant behavior. This suffices to imply that the normal behavior or the antithesis of corruption thus equally means anti-corruption. This conception may run into conflict with broader conceptions in terms of operationalization especially in instances where corruption is widespread and regarded as the norm by majority of the people. Similarly, Samuel P. Huntington (1968) conjectured and likened corruption to behavior of public officials, which deviates from accepted norms in order to serve private end. The International Monetary Fund (IMF) and World Bank defined corruption as "the abuse of public office." According to the World Bank, corruption is the abuse of public office through the instrumentality of private agents, who actively offer bribes to circumvent public policies and processes for competitive advantage and profit. Beyond bribery, public office can also be abused for personal benefit through patronage and nepotism, for example the theft of state assets or the diversion of state revenues. This is a very wide-ranging definition, which delineates some of the acts of corruption. And it agrees with Otite's interpretation of the meaning of corruption as the perversion of integrity or state of affairs through bribery, favor or moral depravity (Otite, 1986)

Further to the above, The Transparency International equally defines corruption as behaviour on the part of officials in the public sector, whether politicians or civil servants, in which they improperly and unlawfully enrich themselves, or those close to them, by the misuse of public power entrusted to them (Cited in Pope, J. 1996). Although the definition of the Transparency International is very descriptive, it focuses only on the public sector. But there is corruption in private sector with negative consequences for the whole of society. Similarly, El-Rufai (2003) viewed corruption as covering a wide range of social misconducts, including fraud, extortion, embezzlement, bribery, nepotism, influence peddling, bestowing of favor to friends, rigging of elections, abuse of public property, the leaking of a government secret, and sale of expired and defective goods, such as drugs, food, and electronic and spare parts to the public, etc.

From the foregoing however, it can be opined that in as much as we strive to understand and conceive what corruption is all about, it will continue to elude a universally accepted conceptualization due to its constructivist posture. Sufficed to mean, that corruption can fully be grasped when located within our unique and local cultural understanding and context. This goes to say that our meanings and interpretation of corruption is locally and culturally constructed. For instance, while the act of gratitude whether in kind or otherwise is considered an act of corruption in some societies, it's culturally entrenched in some societies. So therefore, understanding and determining an act of corruption will continue to be a herculean task because of its constructivist view and fluidity.

However, we can carefully understand dynamics of corruption and how it manifests in all spheres of human formations through some of its categorization and typologies.

\subsection{Categorization and Typologies of Corruption}

Corruption can be categorized from different perspectives. Corruption can be classified according to how it is carried out in relation to established rules in administration. There are two types of corruption in this regard. The first is done "according to the rule" where an official receives private gain for doing what he/ she is paid to do. The second is done "against the rule" where an official is paid bribe to give services that he/ she is prohibited from providing. (Pope, Ibid). Corruption can also be classified according to the scale i.e. petty or survival corruption and grand corruption Petty or 
survival corruption is practiced by civil servants, who may be grossly underpaid and depend on small rents from the public to feed their families and pay school fees (Pope, Ibid). The grand corruption is practiced by high public officials and it often involves large sums of money.

Corruption has also been classified based on the spheres or arena of special activities where it takes place. Using this criterion, Otite (Ibid) classified corruption into five groups: Political corruption, Economic Corruption, Bureaucratic corruption, judicial corruption and moral corruption.

\subsubsection{Political Corruption}

This usually manifests in activities connected with election and succession, and the manipulation of people and institutions in order to retain power and office.

This is rooted in the character of African politics generally that is based on winners-takes-it-all and win-at-all-cost syndromes where high political largesse is attached to public offices. This explains the competition for such resourcespositions and why people engage in extra-legal means through corruption in order to overcome obstacles and opposition. Similarly, high-profile corrupt cases within the political class can be captured in this category. Both Nigeria and South Africa are not exempted from this form of corruption. The subsidy and Stella Oduah's car scandals in Nigeria and the Nkandla affairs in South Africa are only a handful of the many examples of high-profile political corruption cases in both countries.

\subsubsection{Economic Corruption}

It occurs when business people use corrupt means to pervert the normal institutional regulations, hasten or shorten procedures and get undue advantage or value for goods and services. This is manifested in cases of tax evasion, deliberate inflation of contract quotations, and provision of substandard goods and services as well as customers' exploitation.

\subsubsection{Bureaucratic Corruption}

It involves buying favors from bureaucrats, who formulate and administer government economic and political policies including foreign exchange, privatization exercises, import licenses, taxes etc. It is the sum of all corrupt practices that take place within governmental institutions. It manifests in favoritism and nepotism in appointment, promotion and reward systems in public offices. Some persons get rapid promotion and rewards on the basis of family, friendship, ethnic or religious affiliations to the boss; while some never get promotion because of such frivolous considerations.

\subsubsection{Judicial Corruption}

It occurs when law enforcement agencies and the courts pervert the administration of justice.

\subsubsection{Socio-Cultural $\backslash$ Moral Corruption}

This occurs when people engage in practices that are morally reprehensible.

\section{Military Corruption}

This is associated with military ruler ship and common in military organizational structure. It is quite ironical that the military that sees itself as a corrective mechanism to bad leadership and corruption could be found wanting and neckdeep in the same menace. This was the case with the Babangida and Abacha's regimes which, despite the claims that they struck due to the pervasive level of corruption of the democratically elected governments they dislodged, came under the spotlight as the two most corrupt leaderships in the country (TI, 2004). The intrusion of the military into the political arena in post-independence Nigeria has only succeeded in aggravating income distortion (Dibie, 2007). Considering the level of corruption and economic waste under successive military regimes and the poor resource management under the civil rule of the Second Republic, not only was the gap between the rich and the poor became widened, but the real income of the majority also plummeted to starvation level (Omotola, 2008). Although, South Africa has not experienced military incursion in politics since the end of the Apartheid regime but its Nigerian counterpart has had, as claimed by the military, reasons to experience the Iron hand of the military in her politics. One would have thought that due to the Discipline level and No-nonsense approach of the military, the past military governments would have saved Nigeria from the cold hands of corruption but the reverse was the experience. This is why it has been maintained that the current pervasive of underdevelopment in Nigeria and most African states are in part due to the high level of corruption in their past military regimes.

\section{Factors That Often Trigger Corruption in Nigeria and South Africa}

There are different perspectives on what causes corruption in society. Some scholars have argued that poverty is at the root cause of corruption and that without poverty, there would be no corruption (Enweremadu, 2012). Most people would agree that poverty definitely contributes to corruption. In many poor countries, the wages of public and private sector workers are not sufficient for them to survive. Many people therefore engage in petty corruption to make ends meet. But poverty can definitely not be the only explanation. If poverty is the only cause, it will be difficult to explain why rich people and rich countries engage in corruptible transactions. It has been documented that:

Recent World Bank estimates of the wealth, which corrupt African leaders have stashed away in European banks stands at several billion US dollars. None of these leaders can be described as victims of poverty. Yet, by plundering national treasuries, these African leaders have unquestionably deepened the poverty of their people (Pope Ibid) 
There is also the suggestion that corruption is part of the culture of many developing countries (Smith, 2007). This line of argument is mostly pushed by Eurocentric scholars. They argue that what is regarded as corruption in Africa is a myth because it is expected that a beneficiary should show appreciation for a favor granted him/her. If a government official offers one a job or contract, the beneficiary would be obliged to show appreciation either in kind or cash to the government official just as he would do to a village chief if granted a land to cultivate crops or build a house. Corruption is a myth because 'one's culture's bribery is someone else's goodwill. But this position that corruption is part of African culture has been criticized by African scholars, activists and politicians. It is clear to someone of African descent that the traditional African society frowns at corruption or stealing of anything that does not legally belongs to one and there are strong community sanctions for such behaviors. As Maduagwu has argued, it is mere trivialization of the serious issue of corruption in the modern society for anyone to suggest that corruption or embezzlement of public funds or extortion of money (bribes) from people looking for jobs or contracts or other benefits from government could be equated to the customary requirement of bringing presents to the chief for permission to cultivate a land and such things (Maduagwa, 1996). Following Maduagwa's line of thought, Former Nigerian President Olusegun Obasanjo, has also debunked claims that corruption is historically and culturally inherent in African society by informing that it's greed within the African leadership circle as well as extreme poverty amongst the African followership that largely account for the high prevalence of corruption in Africa (Obasanjo, 1995; Diamond, 1991; Dibie, 2007).

\section{An Overview of Anti-Corruption Program in the Fourth Republic}

An endemic culture of corruption has continued to pose obstacles to the realization of development, human rights, and welfare for the Nigerian people. In view of this, the successive governments that came to power put in place various measures, programs, and policies geared towards eradicating corruption in Nigeria. Some of these measures include Murtala/ Obasanjo's Jaji Declaration of the 1970s, Shagari's Ethical Revolution of 1981, and the War against Indiscipline (WAI) by Buhari/ Idiagbon administration in 1984. Although in 1989, Babangida set up committees on corruption and other economic crimes, but his administration never declare war on corruption. In 1994, Abacha's administration introduced War against Indiscipline and Corruption (WAI-C). However, these anti-corruption initiatives remained at the level of rhetoric and did not result in any significant changes.

Similarly, in 1999, when President Obasanjo came to power, he told Nigerians that corruption was the major clog in the wheel of Nigeria's development and, until the social menace is cured, development will continue to elude the country. Consequently, his government put in place different anti-corruption initiatives to deal with the problem. Critical among these are the

Economic and Financial Crime Commission (EFCC), the Independent Corrupt Practices and Other Related Offences Commission (ICPC), the Nigeria Extractive Industries Transparency Initiatives (NEITI), the Public Procurement Act, the Fiscal Responsibility Act, Due Processes, and e-payment to detect and deter embezzlement and other forms of financial fraud. In addition to the above, Obasanjo's government also established anti-corruption departments in some of the federal ministries and parastatals. He rounded up his anti-corruption initiatives with the establishment of the Technical Unit on Governance and Anti-Corruption Reforms (TUGAR) (Ali, 2010). These, amongst others, were the anti-corruption institutions and legal frameworks that were introduced in the current Fourth Republic. These initiatives, at the early life of Obasanjo's administration, were greeted by a lot of hope with the expectation that changes will come to punish those persons who have carried out gross corrupt acts in the past and prevent others in the future from doing likewise. Unfortunately, these programs, policies, and strategies made no meaningful impact in the fight against corruption in Nigeria. For instance, for three consecutive years, 2000, 2001, and 2003, Transparency International, an international, non-governmental, anticorruption organization in its Corruption Perception Index (CPI) ranked Nigeria as the second most corrupt country in the world (Ali Ibid). The unimaginable greed, obtuse and prodigious in thievery, arbitrariness, contempt for rule of law and fundamental human rights, selective investigation of corruption allegations, and poor handling of the economy were only a few of the woes that Nigerians experienced under Obasanjo's administration. Taken a step further, Obasanjo later used the excuse of an anti-corruption crusade to carry out witch hunts of its opponents and perceived enemies of his government. The irony is that the anti-corruption initiatives were unraveled by various investigations into massive acts of corruption by his administration after he left office. Some of the revealing information that have emerged is that the former president waived due process for the contracts awards and gave away vast amounts of Nigeria's hard-earned resources to his friends, family, and political allies. Also, investigation by the House of Representatives into the power sector revealed that Obasanjo's administration wasted public resources to the tune of 16 billion US dollars in the power sector with nothing to show for it.

Furthermore, since the inauguration of Yar'Adua/ Goodluck government in May 2007, the administration has consistently proclaimed the respect for the rule of law and due process as its anchor point. However, the actions of government have left more to be desired as its body language seems to portray the opposite of what it proclaims. Since $\mathrm{Dr}$ Goodluck Jonathan became the substantive president of Nigeria, many cases of corruption have occurred, but the president did not have the tenacity to call for an investigation. Specifically, there has been a decline in the tempo of prosecution of public officers from the previous regime (Ali, 2010). The retention of numerous personalities reputed to be corrupt clearly eroded the credibility of the administration's resolve to fight corruption. It is, therefore, not surprising that the performance of normal state functions, which collapsed under the military, still have not been revived. Many basic facilities, such as water and electricity supply and health and education services, are not working efficiently mainly because of the excessive corruption of state officials, who regularly steal much of the financial allocations of their ministries and parastatals. At this juncture, we can safely conclude that all anti-corruption measures put in place in the fourth republic did not yield the desired result because of the wide gap between the intent and actual practice. Moreover, 
it has been argued that a neo-colonial state cannot meaningfully fight corruption because it is administered on the basis of corruption, executive lawlessness, brigandage, and violence. The ruling cliques, because it does not have faith in the state, engages in systematic looting of the public treasury (Falana, 2010). In line with this, the late President Mobutu of Democratic Republic of Congo (DRC) used to sack ministers who were not indulging in corrupt practices; for him they were wasting their time in the government. In a public rally in 1974, he advised his compatriots to "steal, but steal little by little and invest their fortune in the country" (Nzongola-Ntalaja, 2003). In Africa, Anti-graft agencies are set up to satisfy conditions for the western development assistance, to impress the international community, and deliberately castrate them to render them ineffective. The experiences in Nigeria and other African countries have shown that anti-corruption officials who fail to cover up a corrupt regime and its friends may end up in a shallow grave or exile (Falana, 2010). Thus, since a neo-colonial state cannot allow anti-graft agencies to succeed because of the vested interest, the people would continue to be the greatest victims of official corruption.

\section{Anti-corruption crusades in Nigeria and South Africa: Examining the Convergence and Divergence}

Beyond doubts, it's a plain truth that both Nigeria and South Africa, like other African countries, have had their own share in the problems posed by corruption in recent times in the African continent. For instance, both the apartheid and post-apartheid regimes in South Africa have been victims of the manifestations of this menace. Despite the age-long and high-profile cases of corruption witnessed during the Apartheid regime, the post-apartheid South African has not done enough to put this hydra-headed societal virus in check. Since the commencement and installation of an Indigenous and a democratic government in South Africa in 1994, several top government officials including the incumbent president. Jacob Zuma has been implicated in grand corruption cases. For instance, Jacob Zuma, the South African President, has faced potentially career-killing scandals in time past which range from taxpayer-funded upgrading of his private estate, corruption allegations linked to an arms deal, and a rape charge, on which he was acquitted after arguing he had unprotected but consensual sex with an HIV-positive woman.

The upgrades at Zuma's homestead, which were valued in 2014 at 216 million-rand (then \$24 million), have become a symbol of alleged corruption and greed within the African National Congress' (ANC) government in South Africa. Public Protector Thuli Madonsela, the country's ombudswoman, ruled in 2014 that President Zuma had "benefited unduly" from the work on his Nkandla property, and she said that he should pay back some of the funds. In a U-turn ahead of the court hearing, Zuma has agreed to reimburse some of the costs incurred, in an apparent attempt to end the two-year scandal. The ANC dismissed the case on the pretext that it has "negatively been politicised by the opposition factions. After the recent declaration by the South African High Court that president Jacob Zuma actually defiled the constitution by accepting the upgrading of his Nkandla properties, the president, Jacob Zuma has agreed to pay back some of the money, however, there are still pressure from opposition and the likelihood of facing jail terms and being recalled from his post for corrupt practices. In the case of Stella Oduah's celebrated car scandal in Nigeria, there are doubts that there is ever going to be a legal conclusion as the case continues to be adjourned since the commencement of legal proceeding.

Where there is more competition among high-profiled individuals within the state, anti-corruption policies can be expected to be exploited by the president to purge those perceived as a threat while reinforcing the personal loyalty of others (Chabal \& Daloz 1999). Given that there are very few (if any) powerful individuals who are not guilty of corruption in a predominantly neo-patrimonial political system, a president who can influence who should and who shouldn't be targeted by anti-corruption agencies has a powerful instrument for disciplining followers, while taming or eliminating threats. This played out in how former president Olusegun Obasanjo exploited the Economic and Financial Commission (An agency set up to fight corruption and prosecute corrupt individuals) in his fight against his perceived political enemies. While this barely exists in the South African political landscape, it was an order of the day during President Olusegun Obasanjo's tenure. Similar accusation has been leveled against the incumbent president, President Muhammadu Buhari's administration for prosecuting most of the political associates of former President Goodluck Ebele Jonathan. However, what needs to be affirmed here is the fact the anti-corruption crusade might not be free from political coloration and biases, it is usually, in most cases, directed to people that are guilty of corruption. Where there is a sharp distinction in Nigerian and South African anti-corruption crusades in this, Nigeria may need to separate politics from its anti-corruption drive.

Although, it's a clear fact that speedy and effective prosecution of high-profile corrupt cases is still far from these two countries, there is a relatively higher political will needed in the anti-corruption crusades in one than the other. Failure to curb corruption, in the various dimensions and magnitude that the malaise is manifested in fragile democracies like Nigeria and South Africa (Diamond, 1991:73), has not only threatened democratic sustainability and cripple economic development but also contributed to loss of societal values. It should be noted that while both the Nkandla affairs and Stella Oduah car scandal have lingered for more three years in South Africa and Nigeria respectively, pressure continue to be mounted on the South African Judiciary for a speedy judgment delivery, this pressure had recently resulted in President Zuma agreeing to pay back the said amount to the treasury of the South African government while no one is saying anything nor seems to remember the rape of the Nigerian treasury by Stella Oduah and her accomplices in the car scandal. This is where and how South Africa edges its Nigerian counterpart in their respective fight against corruption. As earlier stated, none of these two countries is free from the claws of corruption yet but one, definitely South Africa is better willed politically to fight this menace than its Nigerian counterpart.

Similarly, while the South African judiciary has complemented the South African people' resolve to put an end to the corruption endemics through its unbiased posture and corrupt-free performance of its constitutional role, same cannot be said of the Nigerian Judiciary where perversion and commoditization of justice holds. This is evidenced in the revelation given by the Ricky Tarfa's case where it was alleged that prominent judges were bribed in order to pervade 
justice. This is not surprising because bribing one's way to achieving the desired results exists virtually in all aspects of national life in Nigeria.

Further to the foregoing, it has been observed that both in Nigeria and South Africa, there is usually undue, perhaps a deliberate, prolonging of trials of corrupt cases unlike what is obtainable in the western world. This gives the perpetrators of corruption room to maneuver and compromise the judicial system. This however suggests that until legal proceeding against corrupt cases are fast-tracked; the political marauders would continue to scuttle the quest of achieving a corrupt-free society.

Similarly, on the question of constitutionalism, there are some provisions of the Constitutions of both South Africa and Nigeria, which seem to be over protecting the accused or perpetrators of corruption against in both countries. Like other law-abiding countries, both South Africa and Nigeria have obliged to the protection of fundamental human rights even in the face of corruption trial. For instance, in Nigeria, Section 35(2) of the Nigerian constitution gives a right to any person arrested or detained to remain silent or avoid answering any question until after consultation with his/ her lawyer while Section 36(11) also provides that any person tried for a criminal offence shall not be compelled to give evidence at the trial. When these rights are claimed, they, many a times, tend to lead to over protection of the accused person while restricting the means of protecting the rest of the society in the sense of making it difficult to prove a case and establish facts against them. This is not peculiar to Nigeria alone; the anti-corruption crusade in South Africa also continues to be hampered by this factor and thus explains why the holistic prosecution of corrupt cases continues to be slowed down.

Furthermore, most suspects in mega bribery are usually either members of the ruling class, party or the sponsors of elected officials (Eme, 2010). Their stooges have always found it impossible to move against them because they are seen either as political godfathers or benefactors. This explains the behaviour of the leadership of the African National Congress (ANC) in South Africa which has consistently debunked the illegality of the action of its own member cum President Jacob Zuma in the Nkandla affairs even after being found to have erred by a court of law. Also, in Nigeria, this manifested during probing of the Halliburton scandal. When the late president Yar'Adua got preliminary report on Hilliburton scam, he could not muster courage to subject past presidents indicted to interrogation over alleged corruption. This stance may account for why he decided to buy time by asking a Special Panel, headed by the Inspector General Police, to probe the Halliburton scandal and till date, the probing of the scandal has not reached a legal conclusion.

Finally, there is a great dissimilarity in the two countries' citizens resolve towards fighting corruption in these countries. While the South African people have been instrumental in the fight against corrupt high-profile politicians through peaceful protests and other constitutional means, the Nigerian people hardly come out to criticize corrupt politicians for primordial's reasons. In fact, Nigerians prefer celebrating convicted corrupt public office holders than condemning this heinous act. Despite being accused and presently undergoing corruption trial in court, Stella Oduah contested the Senatorial seat into the Nigerian National Assembly and won. In fact, this explains why ex-convicts like Bode George, Tafa Balogun and others who have served in various public offices in corrupt manners were given a celebrated welcome and chieftaincy titles upon the completion of the respective jail terms. This attitude again is demonstrated in the latest leaks of Panama papers, which revealed that various world leaders operated shell (fake) companies as means of hiding their wealth from taxes in their countries. In Nigeria, two currently serving Senators including the Senate President names appeared in the leaked document and in spite of this, there is yet to be any concerted public response or demand for some explanations as it was the case in other countries. In fact, leaders of countries like the prime minister of Iceland and a cabinet minister in France have resigned their appointments.

\section{The Way Forward}

While this paper acknowledges the bold efforts that have been committed into the anti-corruption crusades by both the Nigerian and South African Governments, it begs to affirm that there is a possibility of both governments losing out in the anti-corruption if the quest continues to be tossed around by excessive political interference. This paper observes that there are varying degrees of successes recorded in the anti-corruption crusades in both countries, however, there are still challenges of socio-cultural perception of corruption, delay process of resolving corruption cases thereby encouraging impunity and creation of culture of "untouchables" that must be resolved as urgently as possible if any meaningful result is to be achieved. Also, it is equally observed that in the discourse and handling of corruption issues, Nigeria still has a lot to learn from South Africa, corruption still holds sway in both countries.

The paper concludes that a lot still needs to be done not only at the level of policy making or establishment of anticorruption infrastructure but specifically at "Walking the talk" in terms of actual commitment to mitigating corruption in the two countries.

\section{References}

i. Akanbi, M. (2002). "Corruption as an Obstacle to Good governance in Nigeria”, The Nigerian Bar Journal, Vol. 1, No. 3 Pp. 19-26.

ii. $\quad$ Ali, Y (2010). “Mega Bribes: Can Jonathan Touch the Untouchables” The Nation on Sunday, July 4, pp 18 \& 56.

iii. Chabal, P. and J.-P. Daloz. (1999). Africa Works: Disorder as Political Instrument. Bloomington: Indiana University Press.

iv. Diamond, L. (1991). “Nigeria's personal struggle”, Journal of Democracy. 2(4) 73-85.

v. Dibie, R. (2007). "Ethical leadership, Social Responsibility and Corruption in Nigeria”, Aina, A. D. (ed), Corruption and the Challenge of human Development, Ilishan- Remo, Program on Policy, Conflict and Strategic studies, Babcock University. 
vi. El-Rufai, N.A. (2003). "Is Liberal Democracy Encouraging Corrupt Practices: The Privatization Protest?" The Nigerian Social Scientist, a Publication of Social Science Academy of Nigeria, Abuja.

vii. Eme, O.I. (2010). "Corruption in Nigerian Government Institutions: A case of Police Equipment Fund, Journal of Liberal Studies, University of Nigeria, Nsukka, pp, 440-458.

viii. Enweremadu, D.U. (2012). Anti-corruption Campaign in Nigeria (1999-2007): The Politics of a Failed Reform, Paris: African Studies Center.

ix. Falana, F. (2010). "Civil Society and Anti-Corruption Struggle in Nigeria”, The Nation Newspaper, May, 19.

x. Gupta, A. (1995). "Blurred Boundaries: The Discourse of Corruption, the Culture of Politics, and the Imagined State", American Ethnologist, Vol. 22, No. 2

xi. Huntington, S. P. (1968), Political Order in Changing Societies, New Haven: Yale University Press.

xii. Maduagwa, M. O. (1996). "Nigeria in Search of Political Culture: The Political Class, Corruption and Democratisation", in Gboyega, A. Corruption and Democratisation in Nigeria, Ibadan: Friedrich Ebert Foundation and Agbo Areo Publishers.

xiii. Nye, J. S. (1967), "Corruption and Political Development: A Cost Benefit Analysis" the American Political Science Review, Vol.LXI (61) No. 2000.

xiv. Obasanjo, O. (1995), "Corruption, Democracy and Human Rights in Africa" in Aderinwale, A (Ed), Corruption, Democracy and Human Rights in West Africa, The Keynote Address to the Africa Leadership Forum on Corruption, Democracy and Human Rights in Africa held in Cotonou, Benin Republic from 19-21 September, 1994. Ibadan, ALF Publications.

xv. Okojie, P., Momoh, A. (2005). "Corruption and the Crisis of Development in Nigeria," Paper presented at the conference on "Redesigning the State? Political Corruption in Development Policy and Practice," held at Manchester Metropolitan University, 25 November, 2005.

xvi. Omotola, J. S. (2008). From importer to exporter: The changing role of Nigeria in promoting democratic values in Africa. in Pretorious, J. (ed) African Politics: Beyond the third wave of democratization. Cape Town, Juta and Co. Ltd. pp 33-51.

xvii. Otite, O. (1986), "Sociological Study of Corruption" in Odekunle, F. (ed), Nigeria: Corruption in Development, Ibadan: Ibadan University Press

xviii. Pope, J. (1996), National Integrity Systems: The TI Source Book, Berlin: Germany, Transparency International.

xix. Smith, O. J. (2007). A culture of corruption: Everyday deception and popular discontent in Nigeria, Oxford: Princeton University press.

xx. The Oxford Dictionary of Current English

xxi. World Bank: Helping Countries Combat Corruption, Washington DC, USA. Cited in Bello-Imam, I. B. (2005), the War against Corruption in Nigeria: Problems and Prospects, Ibadan: College Press and Publishers Ltd 